\title{
Hepatoprotective activity of Punica granatum leaf extract against Carbon Tetrachloride induced
} Hepatotoxicitv in Rats

Manoj Kumar ${ }^{1, *}$, Sukumar Dandapat ${ }^{1}$ and Manoranjan Prasad Sinha ${ }^{1}$

Department of Zoology, Ranchi University, Ranchi - 834008, Jharkhand (India)

epartment of Zoology, St. Xavier's College, Ranchi - 834001, Jharkhand (India)

E-mail address: dr17mk@gmail.com

Peer-reviewed by: Gabriela Dogaru, "Iuliu Haţieganu" University of Medicine and Pharmacy Cluj-Napoca

Florina Ojoga, National Institute of Rehabilitation, Physical Medicine and Balneology, "Carol Davila” University of Medicine and Pharmacy

\section{Abstract}

In the present study Hepatoprotective activity of aqueous leaf extract of Punica grantum on total protein, bilirubin, aspartate aminotransferase (AST), alanine transaminase (ALT) and alanine phosphatise (ALP) in CCl4 intoxicated rat were studied. Administration of CCl4 showed significant increase $(\mathrm{p}<0.01)$ in liver marker enzymes in serum namely AST $(52.30 \pm 1.15$ to 107.2 $\pm 13.7 \mathrm{IU} / \mathrm{L}), \operatorname{ALT}(146.63 \pm 5.79$ to $206.2 \pm 28.82 \mathrm{IU} / \mathrm{L}), \operatorname{ALP}(176.24 \pm 5.8$ to $508.2 \pm 10.22 \mathrm{IU} / \mathrm{L})$, bilirubin $(0.52 \pm 0.09$ to $2.61 \pm 0.27 \mathrm{mg} / \mathrm{dl})$ and significantly decreased total protein $(9.57 \pm 0.17$ to $5.2 \pm 0.085 \mathrm{mg} / \mathrm{dl})$, when compared to normal. Aqueous extract of Punica grantum at $250 \mathrm{mg} / \mathrm{kg}$ and $500 \mathrm{mg} / \mathrm{kg}$ body weight showed significant increase in total protein (5.2 \pm 0.085 to $6.1 \pm 0.023 ; 6.5 \pm 0.033$ ) as compared to CCl4 treated rats. The extract lowered enzyme levels which is designation of Hepatoprotective action of extract. The serum AST, ALT and ALP levels are reliable markers of liver function. Thus the present study concludes the aqueous leaf extract of Punica grantum to possess Hepatoprotective activity.

Key words: alanine transaminase, alkaline phosphatases, CCl4, aspartate aminotransferase

\section{INTRODUCTION}

Diseases like jaundice, cirrhosis and fatty liver are commonest liver diseases worldwide. In India numerous medicinal plants such as Adhatoda vasica, Psidium guajava, Coccinia indica etc... are employed for treatment of liver related disorders. Punica granatum is traditionally used medicinal plant in India. Punica granatum has been reported to possess antimicrobial, antioxidant and reducing power ability (Kumar et al., 2015). Free radicals or oxidative injury now appears to be the fundamental cause behind a number of mammalian diseases (Parvathi et al.,2013). The mammals have a complex antioxidant system to combat the oxidative stress. However excessive reactive species derived from oxygen and nitrogen may still lead to oxidative damage to tissue organs. Oxidative stress has been considered as a conjoint pathological mechanism and it contributes to initiation and progression of liver injury (Sha et al., 2015). Various plants are scientifically proven to posses Hepatoprotective activity, and the underlying mechanisms involve the antioxidant property of the plants (Kumar et al., 2013a). Effects of antioxidants or free radical scavengers have been widely tested for the prevention and treatment of acute and chronic liver injuries. In some of the studies, antioxidants have shown beneficial effects, specially for prevention and treatment of liver injury (Kukongviriyapan et al., 2013; Kumar et al., 2014a). The present study was undertaken to investigate the Hepatoprotective activity of aqueous leaf extract Punica grantum leaf extracts in $\mathrm{CCL}_{4}$ induced Hepatotoxicity in rats.

\section{Materials and Methods:}

Plant materials: The fresh tender leaves of Punica grantum was collected. The leaves were washed with deionised water and disinfected with $0.1 \% \mathrm{HgCl}_{2}$ solution for $5 \mathrm{~min}$ and dried in shade away from direct light for 20 days and ground to fine powder using electrical griender. The powder obtained was sieved and stored in air tight containers for future use (Kumar et al., 2014b).

Preparation of leaf extracts: the fine powder of Punica grantum was made into thimble for loading in Soxhlet apparatus and extraction was done using distilled water. The extraction was continuously done for 72 hours. The extracts thus obtained were concentrated in vacuum rotary evaporator and extracts were kept in dessicator until used (Kumar et al., 2014b; Dandapat et al., 2014c)

\section{Phytochemical screening: preliminary phytochemical screening were conducted on Punica}


granatum in accordance to previously published standards (Kumar et al., 2014b).

Antioxidant properties: The antioxidant properties of plant sample was determined by Spectrophotometric quantitation method (Prieto and pineda, 1999; Ferreira et al., 2007; Ghosh et al., 1984). Various concentrations of samples $(5 \mu \mathrm{g}, 50$ $\mu \mathrm{g}, 100 \mu \mathrm{g})$ were taken in a series of test tubes. Then $1.9 \mathrm{~mL}$ of reagent solution $(0.6 \mathrm{~m}$ Sulphuric acid, $28 \mathrm{~mm}$ Sodiumphosphate and $4 \mathrm{~mm}$ Ammonium molybdate) was added to the test tubes. The tubes were incubated at $95^{\circ} \mathrm{C}$ for $90 \mathrm{~min}$ and allowed to cool down. The absorbance of aqueous solution of each was measured at $695 \mathrm{~nm}$ against blank. Antioxidant capacity was expressed as equivalents of ascorbic acid. Butylated hydroxyl anisole (BHA) was used as reference standard.

Animals: Albino rats weighing about 175-200 g were used in the study. They were maintained under standard laboratory conditions at ambient temperature of $25 \pm 2^{\circ} \mathrm{C}$ and relative humidity at $50 \pm$ $15 \%$, with dark-light cycle of $12 \mathrm{~h}$. Animals were fed with a commercial pellet diet and water ad libitum. The experiment was performed after prior approval of Ethics committee of Ranchi University, Ranchi (Proceeding no. 46, page no. 137).

Acute Toxicity Study: the acute toxicity studies was carried out as per stair case method [20]. 50 albino mice of either sex weighing 20-25g and 90 days were used to determine LD50 of various extracts. The mice were divided into 3 groups of 10 mice each as follows for leaf extract of Punica granatum.

Group 1: Received $1 \mathrm{ml}$ of distilled water orally. Group 2: Received $250 \mathrm{mg} / \mathrm{kg}$ body weight of extract orally.

Group 3: Received $500 \mathrm{mg} / \mathrm{kg}$ body weight of extract orally.

No mortality was observed up to $500 \mathrm{mg} / \mathrm{Kg}$ body weight of leaf extract.

Assessment of Hepatoprotective Activity: All the animals were sacrificed on day 14 under light ether anesthesia. $5 \mathrm{ml}$ of blood was collected from each animal by cardiac puncture using sterile needle and syringe. Part of blood sample was put into test tubes and allowed to clot for $30 \mathrm{~min}$ at $37 \circ \mathrm{C}$. The clear serum was separated at $2500 \mathrm{rpm}$ for $10 \mathrm{~min}$ and biochemical investigations were carried out to assess liver functions viz. Total bilirubin (Kingsley and Frankel, 1939), total protein (Kingsley and Frankel, 1939), serum transaminases (Reitman and Frankel, 1957) and alkaline phosphatise (Bessey et al., 1964).

\section{Results and Discussion:}

The results of phytochemical screening of aqueous leaf extract of Punica grantum is presented as figure 1. Aqueous leaf extract of Punica grantum showed the presence of alkaloids, flavonoids, saponins, tannins and phenolic compounds. The results revealed that flavonoids are present in highest concentration $(81.16 \pm 1.099 \mathrm{mg} / \mathrm{ml})$ and alkaloids are present in lowest concentration (3.075 \pm 1.00 $\mathrm{mg} / \mathrm{ml})$. The results of antioxidant activity of aqueous leaf extract of Punica grantum is presented as figure 2. The leaf extract of Punica grantum showed strong antioxidant activity as compared to standard BHA (Butylated Hydroxyanisole). The results of different parameters of Liver function tests are presented in figure 3 and figure 4 . Figure 3 shows the change in liver function parameters in rats administered with $\mathrm{CCl}_{4}$. The $\mathrm{CCl}_{4}$ has been utilized as an implement to induce Hepatotoxicity in experimental animals (Recnagel, 1983; Okuno et al., 1986). Liver is the main metabolic centre where detoxification and drug metabolism take place which makes it greatly vulnerable to damage by toxic substances (Reddrop et al.,1983). $\mathrm{CCl}_{4}$ caused peroxidative degradation in adipose tissue resulting in fatty infiltration of hepatocytes. The incrementation in the calibres of serum bilirubin reflected the depth of jaundice and incrementation in serum transaminases and alkaline phosphatases was the clear designation of cellular damage and loss of functional integrity of the cell membrane of hepatocytes (Sarwath et al., 1993). The results showed elevation in all parameters under examination.

Aminotransferases include AST (Aspartate transaminase) and ALT (Alanine transaminase). They participate in glucogeogenesis by catalysing the transfer of amino group from aspartic acid or alanine to ketoglutaric acid to produce oxaloacetic acid and pyruvic acid respectively. AST and ALT are an excellent markers of hepatocellular injury. AST is 
present in cytosolic and mitochondrial isoenzymes and is found in the liver, cardiac muscle skeletal muscle, kidneys, brain, pancreas, lungs leucocytes and red cells (Cohen and Kaplan, 2000). It is comparatively less sensitive as compared to ALT. The ALT is a cytosolic enzyme found in highest concentration in the liver, and its test is more specific in determination of liver functional health (Cohen and Kaplan; 2000).

The lowering of enzyme levels is a definite designation of Hepatoprotective action of the drug. The serum AST, ALT and ALP levels are reliable markers of liver function (Sarwath et al., 1993; Cohen and Kaplan, 2000). In our study, the consequential elevation of marker enzymes following administration of $\mathrm{CCl}_{4}$, betokened earnest toxicity engendered by the chemical. The administration of aqueous leaf extract of Punica grantum engendered reduction in AST, ALT and ALP levels and total bilirubin levels. Proteins are the building units of the body and are also the most abundant macromolecules in the cells constituting half of their dry weight and they regulate various physiological and metabolic processes (Jaleel et al., 1996). On administration of $\mathrm{CCl}_{4}$ the total protein content decreased. Shalaby (2009) attributes the significant hypoproteinaemia to the cellular destruction or necrosis of liver with subsequent impairment of the protein synthesis machineries of liver, which synthesized most of the plasma proteins (Guyton and Hall, 1996). An increase in total protein was observed in leaf extract administered animals (Group 1 and Group 2) which indicates the recovery of the protein synthesis machineries of liver. Various liver protective herbal drugs contain a variety of chemical constituents like carotenoids, flavonoids, alkaloids, reducing sugars and saponins etc. [25] (Gupta and Misra, 2006), and in the present study alkaloid, flavonoid, saponin, tannin were found in the aqueous leaf extract of Punica grantum and may be responsible for the Hepatoprotective effect of the extract. Thus it could be suggested that Punica grantum aqueous leaf extract possesses Hepatoprotective activity in this model and may be used in abnormalities related to liver.

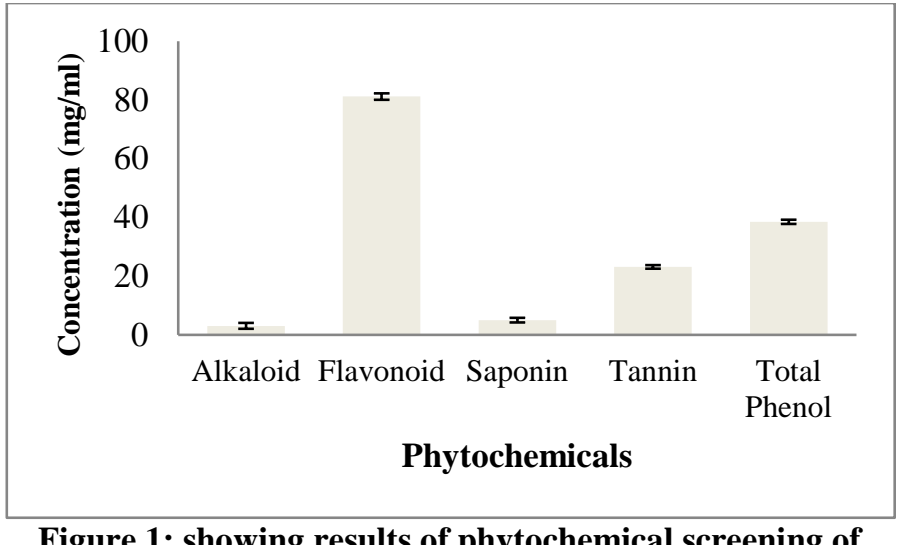

Figure 1: showing results of phytochemical screening of aqueous leaf extract of Punica granatum

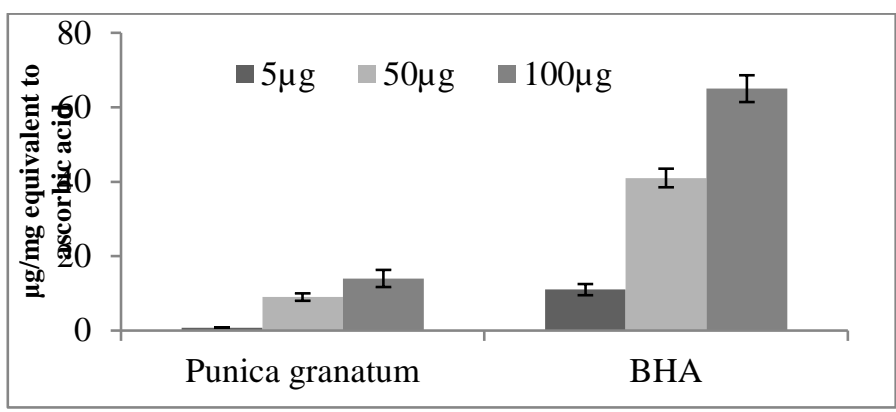

Figure 2: antioxidant activity of aqueous leaf extract of Punica granatum as compared to BHA (Butylated hydroxyanisole)

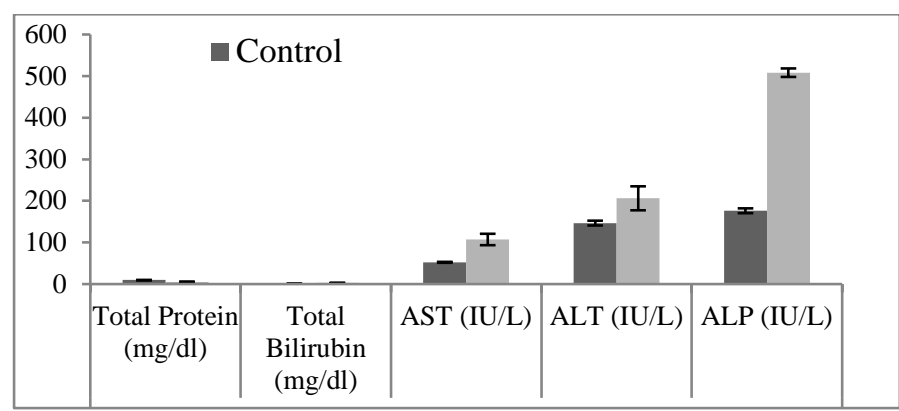

Figure 3Effects of CCL4 treatment on Liver function parameters of albino rats

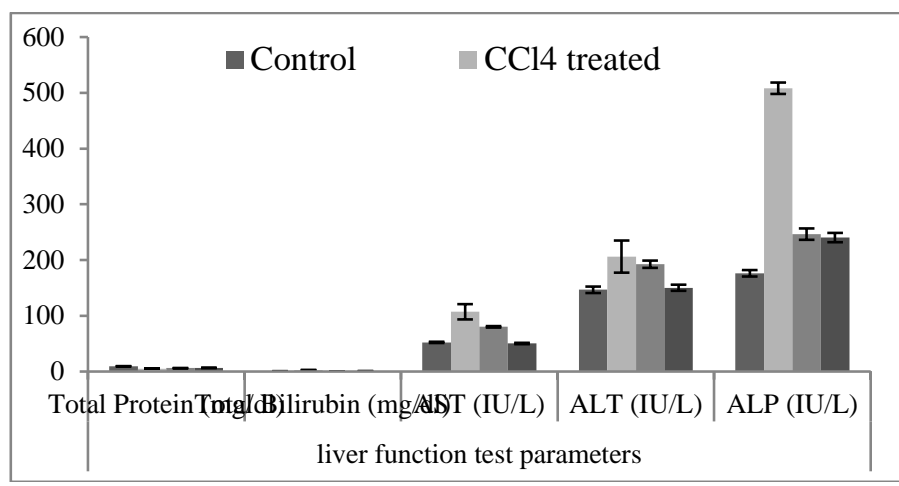

Figure 4: Effects of Punica granatum leaf extracts on liver function parameters of albino rats 


\section{Acknowledgements:}

The authors acknowledge the Lab facilities extended for this work by the H. O. D., Department of Zoology, Ranchi University, Ranchi. The authors are further thankful to the Principal, St. Xavier's College, Ranchi and H. O. D., Department of Zoology, St. Xavier's College, Ranchi for their continuous support and motivation without which this work may have not been completed.

\section{Bibliography}

1. Kumar, M., Dandapat, S., Sinha, M. P. 2015. Phytochemical screening and antibacterial activity of aqueous leaf extract of Punica granatum. Balneo Research Journal, 6(3): 168 - 171.

2. Parvathi, K. M. M., Ramesh C. M., Krishna V., Shankarmurthy, Kuppast I. J. and Shakunta N. M. 2013. Hepatoprotective activity of Anogeissus latifolia leaf and bark extracts against carbon tetrachloride induced Hepatotoxicity in rats. The Bioscan, 8(2): 649 $-653$.

3. Sha Li., Hor-Yue T., Ning W., Zhang-jin Z., Lixing L., Chi-Woon W., Yibin F. 2015. The role of oxidative stress and antioxidants in Liver diseases. International Journal of Molecualr Sciences, 16: 26087 - 26124

4. Kumar, M., Dandapat, S., and Sinha, M. P., 2013(a). Determination of nutritive value and mineral elements of Five-leaf Chaste Tree (Vitex negundo L.) and Malabar Nut (Adhatoda vasica Nees). Academic Journal of Plant Sciences, 6(3): 649 - 653.

5. Kukongviriyapan, V., Janyacharoen, T., Kukongviriyapan, U. and Chantaranothai, P. 2003. Hepatoprotective and antioxidant activities of Tetracera loureire. Phytother. Research, 17: 717.

6. Kumar, M., Dandapat, S., Sinha, M. P. 2014(a). Pharmacological screening of leaf extract of Adhatoda vasica for therapeutic efficacy. Global Journal of Pharmacology, 8(4): 495 - 500.

7. Kumar, M., Dandapat, S., and Sinha, M. P. 2014(b). Plant mediated synthesis of silver nanoparticles using Adhatoda vasica aqueous leaf extract. The Ecoscan, V (Special issue): $29-36$.

8. Kumar, M., Dandapat, S., and Sinha, M. P. 2014(c). Effect of Vitex negundo aqueous extract on serum lipid variable and haematological profile of albino rats. The Ecoscan V (Special issue): 135 - 150.

9. Dandapat, S., Kumar, M., Kumar, A., and Sinha, M. P. 2014. Effects of Aegle marmelos (L.) leaf extract and green nanoparticles on lipid profile. The Ecoscan V (Special issue): 157 - 167.

10. Kumar, M., Kumar, A., Dandapat, S., and Sinha, M. P. 2013(b). Phytochemical screening and antioxidant potency of Adhatoda vasica and Vitex negundo. The Bioscan, 8(2): 727 - 730.

11. Prieto, P. and Pineda, M. 1999. Spectrophotometric quantitation of antioxidant capacity through the formation of a phosphomolybdenum complex: specific application to determination of vitamin E1. Analytical Biochemistry, 269: 337-341.

12. Ferreira, ICFR, Baptista, M., Vilas-Boas and Barros L. 2007. Free radical scavenging activity and reducing power of wild edible mushrooms from northeast Portugal: in individual cap and stipe activity. Food Chemistry, 100: 1511 - 1516.

13. Ghosh, M. N. 1984. Fundamentals of experimental pharmacology, $2^{\text {nd }}$ edition. Calcutta. Scientific Book Agency, p. 156.

14. Kingsley, S. R. And Frankel, S. J. 1939. The determination of serum total protein albumin and globulin by the biuret reaction. J. Biol. Chem., 128 131.

15. Reitman, S. And Frankel, S. A. 1957. Colometric method for the determination of serum goutamisc oxolacetic and pyruvic transaminase. Am. J. Clin. Pathol., 28 - 56.

16. Bessey, O.A., Lowery D. H. And Brock, M. J. 1964. A method for the rapid determination of alkaline phosphatise with five cubic meters of serum. J. Biol. Chem., 164: 321.

17. Recnagel, R. O. 1983. Carbon tetrachloride Hepatotoxicity status quo and future prospects. Trends Pharmacol., 4: 129 - 131.

18. Okuno, H., Hazama, H., Muzare, T. and Shiozaki, S. (1986). Carbon tetrachloride Hepatotoxicity. Pharmacology, 41:363.

19. Reddrop, C. J., Cheeseman, K. H. and Slater T. F. (1983). Correlations between common tests for assessment of liver damage. Cell biochem. Func., 1: $55-63$

20. Sarwath, B., Visen P. K., Patnaik, H. K. and Dhwan, B. N. (1993). Anticholestic effect of picrolive active Hepatoprotective principle of Picrorhiza kurrooa, against carbon tetrachloride induced cholestatis. Indian J. Exp. Biol., 31: 316.

21. Cohen, J. A., Kaplan M. M. (2000). Evaluation of abnormal liver enzyme results in asymptomatic patients. N. Engl. J. Med., 342: 1266 - 1271.

22. Jaleel, C. A. (2008). Interactive effects of triadimefon and salt stress on antioxidative status and ajmalicine accumulation in Cathranthus roseus. Acta physiologiae plantarum, 30: 287 - 292

23. Shalaby, A. (2009). The opposing effects of ascorbic acid (Vitamin C) on ochratoxin toxicity in Nile Tilapia (Oreochromis noloticus). Acta Polenica 2: 18-22.

24. Guyton, C. and Hall, E. J. (1996). Text book of medical physiology, Winth. W. B. Saunders Company, USA.

25. Gupta, A. K. and Misra, N., 2006. Hepatoprotective activity of aqueous land Ethanolic extract of Chamonile capitula in paracetamol intoxicated albino rats. American J. Pharmacol. Toxicol, 1: 17 - 20 